Research, part of a Special Feature on Ecological Restoration in Northern Regions

\title{
Damned If You Do, Dammed If You Don't: Debates on Dam Removal in the Swedish Media
}

\author{
Dolly Jørgensen $^{l}$ and Birgitta Malm Renöfält ${ }^{l}$
}

\begin{abstract}
Dam removal is an increasingly common practice. Dams are removed for various reasons, with safety, economics, and ecosystem restoration being the most common. However, dam removals often cause controversy. Riparian land owners and local communities often have a negative view of removal, and their reasons vary. It may be the loss of recreational benefits such as swimming and boating, loss of cultural and historical context tied to the dam, or fear that removal may have a negative effect on aesthetic values. Because controversies are often picked up by local media, and media in itself is an important channel to build support around a cause, the way in which dam removals are reported and discussed in the media is likely to influence the debate. Here, we examine the ways in which proponents and opponents of dam removal frame the services provided by two contrasting ecosystems, i.e., an existing dam and the potential stream without a dam, by performing a media discourse analysis of the reasons given for removal and the reasons presented for the dam to remain in place. Our source material includes Internetbased newspaper articles and their associated public comments in four dam removal controversies in Sweden. Our analysis indicates that public opposition is not based on knowledge deficiency, where more information will lead to better ecological decision-making, as is sometimes argued in dam removal science; it is instead a case of different understandings and valuation of the environment and the functions it provides.
\end{abstract}

Key Words: controversies; dam removal; discourse analysis; ecosystem services; newspaper media; Sweden

\section{INTRODUCTION}

"All dams that do not have a societally important function should be removed!"'

(Comment from online newspaper article "Dammarna rivs?" 18 May 2011)

This call for dam removal was voiced as part of an ongoing controversy over the removal of two former electricity dams in Sweden. The commentator took the position that these two dams, which no longer produce electricity, serve no function: they are obsolete. But is the electricity provided by a hydropower dam its only societally important function? How are other functions beside a dam's originally engineered one discussed within dam removal debates?

Dams are being removed from watercourses for various reasons. Many older dams require repairs to avoid becoming a safety hazard, and these safety concerns trigger a debate about whether to repair the dam or remove it. The prospect of changing run-off patterns under climate change has led to the overhaul of dam safety in Sweden, and many dams may need improvement to cope with increased discharge (Lejon et al. 2009). Removal is often the most economically viable choice, especially when the dam no longer fulfills its original function. In the Swedish case, environmental policies and commitments such as the EU Water Framework Directive (Directive 2000/60/EC) and Swedish national Environmental Objectives (http://www.miljomal.nu/Environmental-Objectives-Portal/) are increasingly driving forces for dam removal, with the goal of enhancing ecosystem health. For example, several smaller dams have been removed around Sweden to open up access to upstream spawning grounds and improve conditions for Red-listed species such as freshwater pearl mussel (Margaritifera margaritifera).

However, dam removals may cause controversy (Lejon et al. 2009). Riparian landowners and local communities often have a negative view of removal because of the loss of recreational benefits like swimming and boating, loss of cultural and historical contexts tied to the dam, or fear of a negative effect on landscape aesthetics. There has been a tendency within scholarship aimed at ecologists to advocate human behavioral change techniques to lead the opponents of dam removal to agree with "scientific" decisions (e.g., Johnson and Graber 2002, Sarakinos and Johnson 2003), rather than recognizing the validity and rationality of the oppositional position.

Here, we examine the ways in which proponents and opponents of dam removal represent two contrasting ecosystems in the media: an existing dam, and the potential stream without a dam. As Hajer (2005:301) points out, exposing competing discourses "allows a better understanding of controversies, not in terms of rational argumentation, but in terms of the argumentative rationality that people bring to a discussion." Although ecologists involved in dam removal may disagree with the opposition position, they should acknowledge that it is not irrationally constructed. We examine the arguments on both sides to expose how this is not a case of knowledge deficiency in which more information will lead to better ecological decision-making, as dam removal 
science is often characterized (e.g., Stanley and Doyle 2003). Instead, it is a case of different understandings of the environment and the functions it provides.

A potential way of understanding the dam functions invoked in these controversies is to examine them as ecosystem services. Ecosystem services are broadly divided into four categories: provisioning, e.g., the production of food, water, and fuel; regulating, e.g., control of climate and disease; supporting, e.g., nutrient cycles; and cultural, e.g., aesthetic enjoyment, recreation, and spiritual meaning (Millennium Ecosystem Assessment 2005). We know that there will be trade-offs among ecosystem services when management choices must be made (Rodríguez et al. 2006). By invoking ecosystem services, we can examine the positions of proponents and opponents of dam removal as legitimate understandings of the environment.

\section{Reading the news}

Social scientists have increasingly turned to framing theories to understand environmental controversies. According to Schön and Rein (1994:24), it is useful to consider frames as stories "in which the author describes what is wrong and what needs fixing." Frames contain definitions of the issues, prescriptions about suitable responses, assertions of rights, justifications for positions, and calls for action (Gray 2003). Frames therefore consist of beliefs, values, and perspectives that help individuals and groups create coherence and meaning, leading to action in policy matters. Different stakeholder groups interpret the same conflict through different frames and, in the communication process, attempt to influence how an issue is interpreted by others by bringing certain aspects of the issue to the foreground while relegating other aspects to the background (Buijs et al. 2011).

Framing depends on the stakeholder's point of view. Buijs et al. (2011) found that the frames deployed by the stakeholders in a Dutch national park conflict were related to different cultural representations of nature, with proponents of the park favoring wilderness, and opponents referring to aesthetics and anthropocentric values. In that case, the same issue, i.e., whether or not to establish a national park, was interpreted by the two main stakeholder groups in radically different ways based on different ideas of what constitutes "good" nature. Oppositional pairs such as nature/culture, public/private, and knowledge/ignorance can be particularly strong framing devices (Castro and Gomes 2005). Frames tend to anchor bundled packages of symbols, metaphors, and modes of reasoning that give meaning to an issue (Gamson and Modigliani 1989).

Divergent frames can create unresolvable differences among stakeholder groups (Gray 2004), making it vitally important to understand the frames in play within a certain debate. Because of the increasing number of dam removals both in Sweden and worldwide (Stanley and Doyle 2003, Lejon et al. 2009), examining the frames deployed by proponents and opponents of dam removal allows us to see how the groups set the parameters of environmental debate, which might be beneficial to scientists working on dam removal.

\section{METHODS AND STUDY SITES}

Uncovering the cultural representations underpinning discursive framing in a conflict can involve many approaches, including conducting interviews with stakeholders, reviewing official documents and promotional material, and examining news coverage (e.g., Buijs 2009, Buijs et al. 2011). For this analysis, we focus on the online newspaper coverage of the conflict. News discourse is central to framing policy issues and debates around policy decisions (Gamson 1988). The choice of words in a news article, both what quoted informants say and what journalists choose to write, has great power to shape the understanding of policy conflicts through their invocation of frames (Pan and Kosicki 1993) and can affect public opinion (Gamson and Modigliani 1989). For example, scholars have studied extensively the media's presentation of climate change knowledge and controversy (e.g., Wilkins 1993, Smith 2005, Nielsen and Kjærgaard 2011). Dam removal, like other environmental controversies, can receive significant media attention; thus, the news discourses can affect potential policy outcomes and the way the public understands events.

A study of online newspaper coverage of dam removal debates is particularly appropriate in Sweden because of the high newspaper readership and the prevalence of digital paper editions. More than $75 \%$ of the adult population of Sweden reads a daily newspaper every day; $35 \%$ of adults read the largest online paper, Aftonbladet.se, and local papers dominate the online service for local news (Weibull et al. 2011). Thus, a study of how groups argue for and against dam removal in the Swedish media can give us insights into how the public may understand dams as ecosystem service providers. We acknowledge that online media is only one place that environmental controversies might be represented, so this study is not a comprehensive analysis of the Swedish public's understanding of dam removal, but rather one piece of that understanding.

To identify dam removal controversies in the Swedish online media, we performed Internet keyword searches for dammrivning (dam removal) and variant forms thereof, excluding beaver dam removals. When we found a possible candidate, we performed additional searches for that specific dam location and name. We identified cases that had online coverage meeting two criteria: (1) both opponents and proponents were represented in the coverage, and (2) at least five articles had been published online about the controversy. For each case meeting the criteria, all available online newspaper articles about the dam removal were collected.

We read each online article in the data set to identify what statements were made for and against the dam removal. The arguments were classified in two ways: (1) for or against dam 
removal, and (2) type of frame. The six frame types consisted of the four ecosystem services categories of provisioning, regulating, cultural (which was broken down into the subcategories of recreation, aesthetics, and cultural heritage), and supporting; restoration to a natural state (designated when the position was that the stream should be restored without giving any reasons why this is desirable); and economics. We classified statements in articles written by journalists, letters to the editor, and comments by online newspaper readers. The sample that met our criteria was not large enough to do quantitative analysis or statistics. In spite of this limitation, a qualitative analysis of this kind is useful as a way of exposing the actors' positions and the narratives they tell about dam removal.

\section{Dam removal cases}

We identified four contentious dam removal projects in Sweden covered in the online media that met our selection criteria (Fig. 1). There is no official tally of dam removals in Sweden; however, Lejon et al. (2009), through a query sent out to all County Administrative Boards of Sweden, identified 17 Swedish dams that had been recently considered for removal. Our qualitative investigation of four cases should be seen as a relatively large subsample of the total number of dam removals in the country. The total number of online newspaper articles written by journalists about each case was small (Alby, 10; Hallstahammar, 12; Orsa, 7; Tallåsen, 12), but these articles, plus additional letters to the editor and online comments, were sufficient to expose the contours of the debates qualitatively.

\section{Alby}

The dam removal proposal in Alby on the Ljungan River comprises the demolition of two dams, Alby and Ringdalen, which were built at the end of the 1800s. The owner of the dams, Statkraft (an electrical power utility company), has determined that the dams do not meet the current high flood capacity requirements set by the Swedish power industry's dam safety standards, RIDAS (http://www.svenskenergi.se/ sv/Fakta-pa-webben/RIDAS/). Statkraft is proposing to replace the dams with weirs ( $3 \mathrm{~m}$ high) that will create rapids and hold some water back, although the water level is still expected to be lowered by $1.5-2 \mathrm{~m}$. Statkraft held a town hall meeting 31 August 2011 to inform residents of the proposal. According to a Statskraft representative, the meeting had approximately 100 attendees, and "the majority want to have it stay the way it is today, which was the view we expected" (Engström 2011b). In this meeting Statkraft informed the participants of its planned schedule, during which it would file an application for a permit for removal, technical description, and an Environmental Impact Assessment with the Environmental Court in late 2011; plans for removal were set for the summer of 2013. Statkraft's schedule has been since been delayed.
Fig. 1. Locations in Sweden of the dam removal controversies considered in this study.

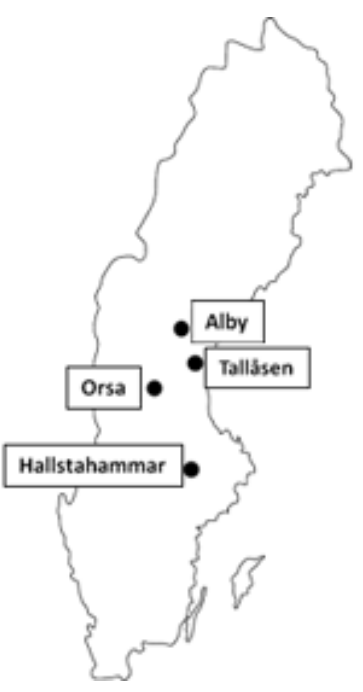

\section{Hallstahammar}

The Hallstahammar controversy also involves two dams: Bruksfallet, built in 1906, and Bultfallet, from 1923. The dams, located in the Kolbäcksån River, are no longer producing electricity. The electrical power utility company, Mälarenergi, was given permission to remove the dams in November 2007. The municipality of Hallstahammar, along with the Administrative Services Agency (Kammarkollegiet) and a local canal preservation board (Kanalbolaget), decided to appeal the permit. In December 2008, the Environmental High Court made a decision to reverse the earlier permit allowance because the dam ponds had been included as functional elements of a newer electricity plant permit. Mälarenergi appealed the decision to the Supreme Court but was unsuccessful.

\section{Orsa}

The Stackmora dam, built circa 1860, is located north of Orsa, on Oreälven. The dam owner, Fortum, was denied permission to build a new dam and power plant downstream of Stackmora in 2007. The municipality opposed the request, claiming that the Ore River is of national interest for tourism and outdoor recreation under 4 kap $2 \S$ i Miljöbalken, and an expansion of the power plant would harm this national interest. The dam partially collapsed in Oct 2008 and then again in Sept 2009. Fortum undertook emergency repairs. The municipality and several interest groups challenged the legality of these repairs, but the Environmental Court approved of the emergency measures. As part of that decision, the Court ordered that Fortum remove the existing dam by 2014. Fortum was also held liable for damages to a fish farm for $450,000 \operatorname{SEK}(52,228$ $€)$ because of the dam breaks. 
Table 1. Summary of the arguments used to support and oppose the removal of four dams in Sweden in media coverage of the conflict, categorized by the frame type invoked.

\begin{tabular}{|c|c|c|c|c|c|c|c|c|}
\hline \multirow[b]{2}{*}{ Frame } & \multicolumn{2}{|c|}{ Alby } & \multicolumn{2}{|c|}{ Hallstahammar } & \multicolumn{2}{|c|}{ Tallåsen } & \multicolumn{2}{|c|}{ Orsa } \\
\hline & Support & Oppose & Support & Oppose & Support & Oppose & Support & Oppose \\
\hline Provisioning & $\begin{array}{c}\text { Fish } \\
\text { migration } \\
\text { routes } \dagger\end{array}$ & $\begin{array}{l}\text { Loss of } \\
\text { pedestrian } \\
\text { access; too } \\
\text { little water } \\
\text { for fish }\end{array}$ & $\begin{array}{c}\text { Increase } \\
\text { biological } \\
\text { diversity; fish } \\
\text { migration } \dagger\end{array}$ & $\begin{array}{c}\text { Loss of } \\
\text { pedestrian } \\
\text { access }\end{array}$ & $\begin{array}{c}\text { Fish } \\
\text { migration } † ; \\
\text { improve } \\
\text { biotope }\end{array}$ & $\begin{array}{c}\text { Negative } \\
\text { effects of } \\
\text { plants/ } \\
\text { animals in } \\
\text { riparian zone }\end{array}$ & $\begin{array}{c}\text { Nationally } \\
\text { important } \\
\text { species }\end{array}$ & $\begin{array}{l}\text { Loss of } \\
\text { productive } \\
\text { river bottom } \\
\text { and shallow } \\
\text { bays }\end{array}$ \\
\hline Regulating & $\begin{array}{l}\text { Risk of dam } \\
\text { failure at high } \\
\text { flow }\end{array}$ & $\begin{array}{l}\text { High flow } \\
\text { without dam } \\
\text { unsafe for } \\
\text { children }\end{array}$ & - & $\begin{array}{c}\text { Dams are a } \\
\text { damage } \\
\text { protection } \\
\text { measure }\end{array}$ & $\begin{array}{c}\text { Less } \\
\text { problems } \\
\text { with property } \\
\text { flooding }\end{array}$ & - & - & $\begin{array}{l}\text { Creeks and } \\
\text { small streams } \\
\text { will dry up }\end{array}$ \\
\hline Cultural: recreation & - & $\begin{array}{c}\text { Loss of } \\
\text { bathing place }\end{array}$ & $\begin{array}{l}\text { Possible to } \\
\text { introduce } \\
\text { trout; stone } \\
\text { pillars remain } \\
\text { for fishing }\end{array}$ & - & $\begin{array}{l}\text { Increase in } \\
\text { angling and } \\
\text { tourism }\end{array}$ & $\begin{array}{l}\text { Loss of fish } \\
\text { farmed for } \\
\text { stream } \\
\text { stocking; less } \\
\text { recreation }\end{array}$ & $\begin{array}{l}\text { Sport fishing; } \\
\text { outdoor } \\
\text { recreation }\end{array}$ & $\begin{array}{l}\text { Salmon and } \\
\text { grayling can } \\
\text { migrate with } \\
\text { current } \\
\text { structure }\end{array}$ \\
\hline Cultural: aesthetics & - & $\begin{array}{l}\text { Loss of } \\
\text { reflecting } \\
\text { pond; views } \\
\text { changed }\end{array}$ & $\begin{array}{c}\text { Running } \\
\text { water }\end{array}$ & $\begin{array}{l}\text { Loss of } \\
\text { reflecting } \\
\text { pond and } \\
\text { views }\end{array}$ & $\begin{array}{c}\text { Free flowing } \\
\text { water }\end{array}$ & $\begin{array}{c}\text { "Naked } \\
\text { muddy" } \\
\text { stream banks; } \\
\text { loss of } \\
\text { reflecting } \\
\text { pond }\end{array}$ & - & - \\
\hline Cultural: heritage & - & $\begin{array}{c}\text { Existed > } 100 \\
\text { yr; village } \\
\text { built around } \\
\text { pond }\end{array}$ & $\begin{array}{l}\text { Stones } \\
\text { remain to } \\
\text { mark dam } \\
\text { locations }\end{array}$ & $\begin{array}{c}\text { Cultural } \\
\text { heritage of } \\
\text { industrial } \\
\text { area }\end{array}$ & - & $\begin{array}{c}\text { Cultural } \\
\text { heritage of } \\
\text { mill, dam, } \\
\text { power station }\end{array}$ & - & $\begin{array}{l}\text { Save "old } \\
\text { culture" }\end{array}$ \\
\hline Restoration & $\begin{array}{l}\text { Restore } \\
\text { "natural } \\
\text { state" }\end{array}$ & $\begin{array}{c}\text { Earlier } \\
\text { judgments } \\
\text { about water } \\
\text { level should } \\
\text { not be } \\
\text { changed }\end{array}$ & $\begin{array}{c}\text { Restore } \\
\text { "natural } \\
\text { stream } \\
\text { environment" }\end{array}$ & - & $\begin{array}{l}\text { Restore } \\
\text { "natural } \\
\text { stream" }\end{array}$ & - & - & - \\
\hline Economics & $\begin{array}{c}\text { No } \\
\text { maintenance } \\
\text { cost }\end{array}$ & - & Reduced cost & - & $\begin{array}{c}\text { Repair too } \\
\text { expensive; } \\
\text { increased } \\
\text { tourism }\end{array}$ & $\begin{array}{l}\text { Loss of } \\
\text { salmon } \\
\text { hatchery }\end{array}$ & $\begin{array}{c}\text { Tourism } \\
\text { money }\end{array}$ & $\begin{array}{l}\text { Support fish } \\
\text { farming }\end{array}$ \\
\hline
\end{tabular}

$\dagger$ In the media coverage, fish migration routes are directly stated as the goal, which is considered a provisioning service resulting in increased fish populations. Note, however, that specific fish (e.g., brown trout) are mentioned as desirable, meaning that recreational fishing is the underlying goal, so the service could be considered cultural-recreation, even though the media does not present it as such.

\section{Tallåsen}

Unlike the other dams in this study, the Kvarn dam in Tallåsen is not owned by an electric company, but rather by the municipality of Ljusdal. In November 2004, the spillway in Kvarn dam on the Sillerbo River collapsed. In response, a provisional weir was built alongside the standing structure, with approval from the Environmental Court until 31 December 2011. In 2006, the municipality asked for help from Kammarkollegiet to prepare a dam removal application. In 2009, the municipality considered selling the dam instead, prompting Kammarkollegiet to retract their help with the permit preparation. In January 2010, the municipality decided not to sell the dam and instead proceed with a removal permit. The permit application was rejected by the Court in May 2012 for failure to include an environmental impact statement. A salmon hatchery located on the dam pond has objected to the removal.

\section{RESULTS AND DISCUSSION}

In our review of the online coverage of these dam removal controversies, we categorized the arguments in news articles made in support of and opposition to the dam removal (Table 1). At a meta-level, proponents and opponents invoke different types of ecosystem services to support their positions. The 
proponents stress the provisioning services of the restored stream, particularly as that provisioning leads to improved recreational fish catches. They often make generic statements about restoring the stream to a "natural state" and bring up the cost of continued maintenance of the dam. The opponents, on the other hand, tend to rely on arguments about the cultural services of recreation, aesthetics, and cultural heritage. Although supporters attempt to counter the oppositions' cultural services arguments, they never make their own arguments directly based on cultural heritage as a service. None of the articles included a supporting ecosystem service argument; this was expected because supporting services such as nitrogen cycling are the least understood by the public (Rodríguez et al. 2006). The proponents and opponents have thus constructed two different discursive packages to support their positions, and those packages have little overlap in terms of the ecosystem services valued.

Through a close reading of the article discourses, we identified three specific characteristics of the discourse that can shape the dam removal controversy: debate fragmentation, a conflict over the aesthetic qualities of still vs. running water, and framing the historical value of nature vs. culture. Not all of these appeared in all of the debates; therefore, we discuss only the debate(s) in which each issue was dominant.

\section{Debate fragmentation}

Online newspaper coverage of the dam removal controversies is often one-sided, with few articles offering both support and opposition viewpoints in the same text (Table 2). Letters to the editor are always more prevalent for the side that is underrepresented in the journalists' articles. In the case of Tallåsen, the journalists have chosen to present primarily articles in favor of removal, whereas the cases of Alby and Orsa have more articles with opposition viewpoints. Press coverage of the Hallstahammar case had the greatest tendency to include both sides in the same article. We were not able to determine the reasons for these biases in press coverage, although the higher frequency of supporting arguments in Tallåsen may be because the dam is owned by the community rather than an outside company. Importantly, these trends mean that readers will have to read a relatively wide sampling of articles on the dam removal to capture both viewpoints.

The development of online commenting features has allowed for more public participation in news coverage. In comparison to standard news articles, these comment streams reveal some differences in the way the public perceives the involved ecosystem services. Contrary to the journalist-authored articles about Tallåsen (Table 1), supporters did not refer to any provisioning services, but there was a reference to the aesthetics of the stream prior to dam construction as revealed in old photographs (Table 3). An opposition commenter noted that fish had yet to return to the stream after the dam's earlier collapse, countering the proposition that migrating fish would come to the area. There was also an exchange between supporters and protesters about the potential effect on property values. This issue was never mentioned in news articles for any of the cases. These comments reveal that members of the interested public bring their own experiences (lack of returned fish, seeing old photographs) into the debate, creating slightly different framing than the main informants and journalists, and emphasizing the fragmented nature of the debate.

Table 2. Fragmentation of media coverage indicated by the inclusion of arguments in support of or opposition to the dam removal in online articles about four Swedish dam removal cases.

\begin{tabular}{llcccc}
\hline \hline $\begin{array}{l}\text { Dam } \\
\text { removal case }\end{array}$ & $\begin{array}{l}\text { Type of } \\
\text { article }\end{array}$ & $N$ & $\begin{array}{c}\text { Support } \\
\text { only }\end{array}$ & $\begin{array}{c}\text { Oppose } \\
\text { only }\end{array}$ & Both sides \\
\hline Alby & $\begin{array}{l}\text { Articles by } \\
\text { journalists }\end{array}$ & 10 & 2 & 5 & 3 \\
Hallstahammar & $\begin{array}{l}\text { Articles by } \\
\text { journalists }\end{array}$ & 12 & 3 & 2 & 7 \\
$\begin{array}{l}\text { Letters to } \\
\text { editor }\end{array}$ & 1 & 1 & 0 & 0 \\
Orsa & $\begin{array}{l}\text { Articles by } \\
\text { journalists } \\
\text { Letters to } \\
\text { editor }\end{array}$ & 7 & 2 & 4 & 1 \\
Tallåsen & $\begin{array}{l}\text { Articles by } \\
\text { journalists } \\
\text { Letters to } \\
\text { editor }\end{array}$ & 12 & 7 & 4 & 0 \\
\hline
\end{tabular}

\section{Still vs. running: beauty is in the eye of the beholder}

The discourse of aesthetics can be polarized in the debate through deployment of the oppositional pair still/running water. Similar to dichotomies such as health/disease, global/ local, and nature/culture, which Castro and Gomes (2005) identified in the media framing of genetically modified foods, this pair becomes a central anchoring point of the frames on both sides of the dam removal controversy.

The opposition position relies on discourse stressing the loss of the dam pond. The pond is characterized as a vattenspegel or spegelvatten, which, directly translated, is mirror water. The stillness of the water in the pond behind the dam has a reflecting, mirror-like effect. This quality of the pond water, which appears to be stationary, is reflected in the colloquial name for this type of dam: spegeldammen (mirror dam). In the opponent discourse, the dam contributes a vital function of slowing the water so that a certain visual aesthetic, the reflecting pond, is created.

The "mirror water" language is used only when talking about what will be lost with dam removal. The vattenspegel is understood as a critical component of the river, as when the mayor of Hallstahammar said, "There is the fear that we won't have any vattenspegel left. A stream without water: how will that look?" (VLT 2004). The opposition may even assume that 
the dam's primary function is to create the pond: One reader commented online that the Tallåsen dams "were built so that we get our vattenspegel in the river" (http://helahalsingland. se/insant/insandare/1.2320979-finns-ingen-demokrati-). The aesthetic quality of the mirror water is an integral piece of the desire to have the pond remain in place.

Table 3. Arguments supporting or opposing dam removal made in comments by online newspaper readers in the Tallåsen, Sweden, dam removal case.

\begin{tabular}{lll}
\hline \hline Frame type & Support & Oppose \\
\hline Provisioning & - & $\begin{array}{l}\text { Benthic fauna and riparian } \\
\text { vegetation harmed; lower } \\
\text { water level }\end{array}$ \\
Regulating & $\begin{array}{l}\text { Address water } \\
\text { problems in house } \\
\text { basements } \\
\text { Trout and grayling } \\
\text { fishing available }\end{array}$ & $\begin{array}{l}\text { Fish have not come back } \\
\text { since dam collapse }\end{array}$ \\
Cultural: recreation & $\begin{array}{l}\text { Old pictures show how } \\
\text { pretty stream was }\end{array}$ & $\begin{array}{l}\text { Dam has high cultural } \\
\text { historical value }\end{array}$ \\
Cultural: aesthetics pond \\
Cultural: heritage & - & $\begin{array}{l}\text { Dam has existed for many } \\
\text { years }\end{array}$ \\
Restoration & Want a natural streach fish come from \\
Economics & $\begin{array}{l}\text { Property values will } \\
\text { rebound }\end{array}$ & $\begin{array}{l}\text { dam; property values will } \\
\text { decrease }\end{array}$ \\
\hline
\end{tabular}

In contrast, the proponents of removal frame the dam removal as bringing back free flowing (fritt strömmande) and running (rinnande) water. The water has rapid movement, being released from the current impounded situation. In the supporter's discourse, free flowing water is framed as valuable. For example, "Running water raises the biological diversity" (Lindqvist 2005), and "We can have a fine flowing water with trout and grayling" (Big Fish 2009). The visual conjured up by the language of flowing water is exactly the opposite of the existing mirror ponds. In fact, one stakeholder pointed out this difference in values: Mats Lindberg of Mälarenergi said, in reference to the Hallstahammar controversy, "Back in time, we thought that there should be mirror ponds, but now we want to have free flowing streams" (Nyheter P4 Västmanland 2007).

This difference in the aesthetic quality of the water, still vs. flowing, is foundational to the framing of the river as a natural object. Depending on aesthetic preferences, one is seen as more beautiful and desirable than the other.

\section{Nature vs. culture: Which history matters?}

There is likewise disagreement about how a dam's history should be valued. The proponents argue for a return to the natural condition of the stream, whereas the opponents argue for the cultural heritage of the human-built structures.
The Alby news coverage includes several informant quotes from the support and opposition that are insightful about the contrast between natural history and cultural heritage framing (Table 4). The proponents' restoration argument is that the stream will be brought back to a more natural state. Naturalness of the river becomes equated with free flowing water; thus, the historical condition of the river prior to the dam is most desirable.

One dam removal protestor directly condemned the argument for restoration. A woman who blogs under the name sexbarnsmamma (mother of six) wrote in a post, "Their argument that they are restoring the environment to be natural is actually as stupid as saying that we should tear away all the asphalt to make the roadside 'natural' again, or why not tear down all the bridges and build wooden bridges instead, as it was before?" (http://sixkidsmom.blogg.se/sexbarnsmamma/2011/ september/dammrivning-neeej.html). In this view, naturalness is not a desirable outcome because it takes away infrastructure that provides functions.

Table 4. Quotations from the Alby, Sweden, dam removal debate about restoration and cultural heritage.

\begin{tabular}{|c|c|c|}
\hline Source of quotation & Restoration & Cultural heritage \\
\hline $\begin{array}{l}\text { Informants quoted in } \\
\text { news articles }\end{array}$ & $\begin{array}{l}\text { "...restore the river } \\
\text { channel to its natural } \\
\text { state" (Anders Sjödin, } \\
\text { Statkrafts dam } \\
\text { technician) } \\
\text { "Remove the dams and } \\
\text { restore nature as near } \\
\text { to the original as } \\
\text { possible" (Arne } \\
\text { Johansson, } \\
\text { Miljöpartiet) }\end{array}$ & $\begin{array}{l}\text { "They have been here } \\
\text { over } 100 \text { years and } \\
\text { should stay" (Sten-Ove } \\
\text { Danielsson) } \\
\text { "The village did not } \\
\text { exist before the dams } \\
\text { were built; it is built } \\
\text { around the water as it } \\
\text { looks today" (Jan } \\
\text { Filipsson, opposition } \\
\text { organizer) } \\
\text { "The dams have been } \\
\text { in place a long time. } \\
\text { This is a question of } \\
\text { customary law" (Tord } \\
\text { Sundquist) }\end{array}$ \\
\hline $\begin{array}{l}\text { Readers' online } \\
\text { comments to news } \\
\text { articles }\end{array}$ & $\begin{array}{l}\text { "Nothing could be } \\
\text { better than free } \\
\text { gushing water and the } \\
\text { most natural } \\
\text { ecosystems as } \\
\text { possible" (Bengt) } \\
\text { "Probably be better } \\
\text { with a bit of river } \\
\text { flowing freely, even if } \\
\text { it is a short stretch" } \\
\text { (Haveröbo) } \\
\text { "Ljungan will be more } \\
\text { natural than it has been } \\
\text { for over } 100 \text { years" } \\
\text { (Lars-Erik) }\end{array}$ & $\begin{array}{l}\text { "[It will] tear down } \\
\text { what we have built up } \\
\text { over generations" } \\
\text { (Uffe) }\end{array}$ \\
\hline
\end{tabular}

The Alby opposition has made claims about the longevity of the dam and the ways in which it has affected society (Table 4). According to this frame, the town's history is dependent 
on the dams and its ponds. As city Councilor Sten-Ove Danielsson observed, "To change the landscape picture after more than a hundred years is not something that is done without reactions" (Engström 2011a). The councilor took the position that the two dams should remain because of their century-long history in the community. The dams thus become a desirable part of the environment. The history of the dam, particularly within the living memory of the residents, becomes key for the opponents because of the services that it has provided: in the case of Alby, there are recreational services in the form of a bathing place on the dam pond.

The Hallstahammar debate is similar to that of Alby. The proponent discourse employs restoration as a frame, using phrases such as: dam removal "restores the river to a more natural condition" (Lindqvist 2005). The opposition, on the other hand, relies primarily on a cultural industrial heritage argument for keeping the dams, founded on the role of city canals fed by dam water: "It is a very important part of the cultural milieu around Strömsholms Canal, and now they want to remove it, and we won't accept it" (Nyheter P4 Västmanland 2006).

The opponent discourse is significant because the cultural heritage argument became the main basis of the oppositions' position statements to the Environmental Court to reject the dam removal application in 2007. The Court decided to approve the permit over these objections because the company Mälarenergi had already set aside the power plant Trångfors on the same river section for cultural heritage preservation. When the dam removal permit was eventually revoked on a technicality, the opponents continued to frame their victory in terms of cultural heritage: "There are those who fight for free waterways to catch more fish and get more bird life and so on, but there are also a few who fought for cultural and industrial history values. ... It's a big part of our industrial heritage, and now it must be preserved" (Nyheter P4 Västmanland 2008). In this statement, we see an acknowledgement that dam removal opponents value a different set of services than the proponents.

\section{CONCLUSION}

There has been a tendency in the scientific community to see environmental conflicts such as dam removal as resolvable, particularly with additional science and/or community outreach through information campaigns (e.g., Babbit 2002, Johnson and Graber 2002). What our analysis shows, however, is that the proponents and opponents of dam removal in these four Swedish cases have different framings of the effects of the dam and its removal. Proponents frame their position with a discursive package, including restoration in general and the ecosystem services of provision (specifically for fish) and recreation (fishing). Opponents generally frame their position in terms of cultural services (recreation, aesthetics, and heritage). The opposition frame does not solely stem from a lack of information about the effects of the removal. Although provisioning and regulating aspects of the oppositions' arguments may be due to lack of understanding, for example, of the function of the dam as flood protection (Table 2), opponents of dam removal understand all too well that with removal, the stream will become a fast flowing, small channel, and they object to that change because it will destroy the cultural ecosystem services they value in the dam. Although additional science and/or community outreach through information campaigns may be beneficial to conflict resolution in some aspects, especially in meeting concerns about riparian development in the former reservoir or arguments about lowered property values (e.g., Orr and Stanley 2006, Provencher et al. 2008) and flood risks, they are likely to be irrelevant when it comes to fundamental differences in how people value the dam's ecosystem services. Technical arguments have little weight when debate involves value judgments and ideological principles (Nelkin 1992).

When two sides in an environmental controversy deploy different frames, it may be difficult, if not impossible, to reach a resolution (Gray 2003, 2004). In the cases presented here, each side in the debate has made insular arguments about the services they value, rarely countering the position for alternate services because such an action would acknowledge the validity of the other frame. Because the two sides place highest value on a different set of ecological services, there is little room for compromise.

As dam removals become more common worldwide, conflicts may become more common. Being aware of stakeholders' possible framing of arguments for and against dam removal might help all parties to understand why conflict can occur and also might assist in developing solutions that recognize the validity of all of the frames. In the end, however, decision makers may have to weigh whether the provisioning services advocated by the proponents or the cultural services touted by the opposition are of more value. Nevertheless, administrative resolution should not be equated with controversy resolution because there are still winners and losers in the dam removal debate.

${ }^{1}$ Media texts quoted in this article were originally published in Swedish. The authors have provided the English translations.

Responses to this article can be read online at: http://www.ecologyandsociety.org/issues/responses. $\mathrm{php} / 5364$

\section{Acknowledgments:}

This research was supported by the Swedish Research Council Formas. 


\section{LITERATURE CITED}

Babbit, B. 2002. What goes up, may come down. BioScience 52(8):656-658. http://dx.doi.org/10.1641/0006-3568(2002) 052[0656:WGUMCD]2.0.CO;2

Big Fish. 2009. Riv kvarndammen till förmån för strömmande vatten! Helähalsingland, 9 June. [online] URL: http://www. helahalsingland.se/insant/insandare/1.1107177-riv-kvarndammentill-forman-for-strommande-vatten-.

Buijs, A. E. 2009. Public support for river restoration. A mixed-method study into local residents' support for and framing of river management and ecological restoration in the Dutch floodplains. Journal of Environmental Management 90 (8):2680-2689. http://dx.doi.org/10.1016/j.jenvman.2009.02.006

Buijs, A. E., B. J. M. Arts, B. H. M. Elands, and J. Lengkeek. 2011. Beyond environmental frames: the social representation and cultural resonance of nature in conflicts over a Dutch woodland. Geoforum 42(3):329-341. http://dx.doi.org/10.1016/ j.geoforum.2010.12.008

Castro, P., and I. Gomes. 2005. Genetically modified organisms in the Portuguese Press: thematization and anchoring. Journal for the Theory of Social Behaviour 35 (1):1-17. http://dx.doi.org/10.1111/j.0021-8308.2005.00261. $\mathrm{x}$

Engström, M. 2011a. Förfular något fruktansvärt. Dagbladet, 18 May. [online] URL: http://www.dagbladet.se/nyheter/ ange/1.3175323--forfular-nagot-fruktansvart-.

Engström, M. 2011b. Albyborna: vi vill ha kvar dammarna. Dagbladet, 2 September. [online] URL: http://www. dagbladet.se/nyheter/ange/1.3864810-albyborna-vi-vill-ha-kvardammarna.

Gamson, W. A. 1988. The 1987 distinguished lecture: a constructionist approach to mass media and public opinion. Symbolic Interaction 11(2):161-174. http://dx.doi.org/10.1525/ si.1988.11.2.161

Gamson, W. A., and A. Modigliani. 1989. Media discourse and public opinion on nuclear power: a constructionist approach. American Journal of Sociology 95(1):1-37. http:// dx.doi.org/10.1086/229213

Gray, B. 2003. Framing of environmental disputes. Pages 11-34 in R. J. Lewicki, B. Gray, and M. Elliot, editors. Making sense of intractable environmental conflicts: concepts and cases. Island Press, Washington, D.C., USA.

Gray, B. 2004. Strong opposition: frame-based resistance to collaboration. Journal of Community and Applied Social Psychology 14(3):166-176. http://dx.doi.org/10.1002/casp.773

Hajer, M. A. 2005. Coalitions, practices, and meaning in environmental politics: from acid rain to BSE. Pages 297-315 in D. R. Howarth and J. Torfing, editors. Discourse theory in
European politics: identity, policy and governance. Palgrave Macmillan, London, UK.

Johnson, S. E., and B. E. Graber. 2002. Enlisting the social sciences in decisions about dam removal. BioScience 52 (8):731-738. http://dx.doi.org/10.1641/0006-3568(2002)052 [0731:ETSSID]2.0.CO;2

Lejon, A. G. C., B. M. Renöfält, and C. Nilsson. 2009. Conflicts associated with dam removal in Sweden. Ecology and Society 14(2): 4. [online] URL: http://www. ecologyandsociety.org/vol14/iss2/art4/.

Lindqvist, R. 2005. Dammar river upp känslor. VLT, 26 October. [online] URL: http://www.vlt.se/nyheter/

hallstasura/1.200482-dammar-river-upp-kanslor.

Millennium Ecosystem Assessment. 2005. Ecosystems and human well-being: synthesis. Island Press, Washington, D.C., USA.

Nelkin, D. 1992. Science, technology, and political conflict: analysing the issues. Pages ix-Xxv in D. Nelkin, editor. Controversy: politics of technical decisions. Third edition. Sage, Newbury Park, ??state??, USA.

Nielsen, K. H., and R. S. Kjærgaard. 2011. News coverage of climate change in Nature News and ScienceNOW during 2007. Environmental Communication: a Journal of Nature and Culture 5(1):25-44. http://dx.doi.org/10.1080/17524032.2010.520722

Nyheter P4 Västmanland. 2006. Tvist om dammar ska nu avgöras. Sveriges Radio, 31 October. [online] URL: http:// www.sverigesradio.se/sida/artikel.aspx?programid=112\&artikel=1009529.

Nyheter P4 Västmanland. 2007. Dammar i Hallstahmmar får rivas. Sveriges Radio, 12 November. [online] URL: http:// www.sverigesradio.se/sida/artikel.aspx?programid=112\&art$\underline{\mathrm{ikel}=1712540 .}$.

Nyheter P4 Västmanland. 2008. Ny dom: dammarna i Kolbäcksån blir kvar. Sveriges Radio, 24 December. [online] URL: http://www.sverigesradio.se/sida/artikel.aspx? programid $=112 \&$ artikel $=2529718$.

Orr, C. H., and E. H. Stanley. 2006. Vegetation development and restoration potential of drained reservoirs following dam removal in Wisconsin. River Research and Applications 22 (3):281-295. http://dx.doi.org/10.1002/rra.891

Pan, Z., and G. M. Kosicki. 1993. Framing analysis: an approach to news discourse. Political Communication 10 (1):55-75. http://dx.doi.org/10.1080/10584609.1993.9962963

Provencher, B., H. Sarakinos, and T. Meyer. 2008. Does small dam removal affect local property values? An empirical analysis. Contemporary Economic Policy 26(2):187-197. http://dx.doi.org/10.1111/j.1465-7287.2008.00107.x 
Rodríguez, J. P., T. D. Beard, Jr., E. M. Bennet, G. S. Cumming, S. J. Cork, J. Agard, A. P. Dobson, and G. D. Peterson. 2006. Trade-offs across space, time, and ecosystem services. Ecology and Society 11(1): 28. [online]. URL: http:// www.ecologyandsociety.org/vol11/iss1/art28/.

Sarakinos, H., and S. E. Johnson. 2003. Social perspectives on dam removal. Pages 40-55 in W. L. Graf, editor. Dam removal research: status and prospects. H. John Heinz III Center for Science, Economics and the Environment, Washington, D.C., USA.

Schön, D. A., and M. Rein. 1994. Frame reflection: toward the resolution of intractable policy controversies. BasicBooks, New York, New York, USA.

Smith, J. 2005. Dangerous news: Media decision making about climate change risk. Risk Analysis 25(6):1471-1482. http://dx.doi.org/10.1111/j.1539-6924.2005.00693.x

Stanley, E. H., and M. W. Doyle. 2003. Trading off: the ecological effects of dam removal. Frontiers in Ecology and the Environment 1(1):15-22. http://dx.doi.org/10.1890/1540-9295 (2003)001[0015:TOTEEO]2.0.CO;2

VLT. 2004. Protester mot dammrivning. VLT, 20 November. [online] URL: http://www.vlt.se/nyheter/hallstasura/1.185409protester-mot-dammrivning.

Weibull, L., A. M. Jönsson, and I. Wadbring. 2011. Media landscape: Sweden. European Journalism Centre, Maastricht, The Netherlands. [online] URL: http://www.ejc.net/ media landscape/article/sweden/.

Wilkins, L. 1993. Between facts and values: print media coverage of the greenhouse effect, 1987-1990. Public Understanding of Science 2(1):71-84. http://dx.doi. org/10.1088/0963-6625/2/1/005 